\title{
Land use effects on soil organic carbon sequestration in calcareous Leptosols in former pastureland - a case study from the Tatra Mountains (Poland)
}

\author{
K. Wasak and M. Drewnik \\ Jagiellonian University, Institute of Geography and Spatial Management, Department of Pedology and Soil Geography, \\ Gronostajowa 7, 30-387 Kraków, Poland
}

Correspondence to: M. Drewnik (marek.drewnik@uj.edu.pl)

Received: 27 March 2015 - Published in Solid Earth Discuss.: 7 May 2015

Revised: 2 July 2015 - Accepted: 21 September 2015 - Published: 7 October 2015

\begin{abstract}
The purpose of the paper is to describe soil organic carbon (SOC) sequestration rates in calcareous shallow soils in reforested areas in the Tatra Mountains with a particular focus on different forms of organic matter (OM) storage. Three plant communities creating a mosaic on the slopes of the studied valley were taken into account.

Fifty years since the conversion of pastureland to unused grassland, dwarf pine shrub and larch forest have emerged in the study area, along with the development of genetic soil horizons as well as SOC sequestration in the soil despite the steepness of slopes. SOC stock was measured to be the highest in soils under larch forest $\left(63.5 \mathrm{Mg} \mathrm{ha}^{-1}\right)$, while in soil under grassland and under dwarf pine shrub, this value was found to be smaller (47.5 and $42.9 \mathrm{Mg} \mathrm{ha}^{-1}$, respectively).

The highest amount of mineral-associated OM inside stable microaggregates (MOM FF3) was found in grassland soil (21.9-27.1\% of SOC) and less under dwarf pine shrub (16.3-19.3\% of SOC) and larch forest (15.3-17.7\% of SOC). A pool of mineral-associated OM inside transitional macroaggregates (MOM FF2) was found in soil under dwarf pine shrub (39.2-59.2\% of SOC), with less under larch forest (43.8-44.7\% of SOC) and the least in grassland soil (37.9$41.6 \%$ of SOC). The highest amount of the free light particulate fraction (POM LF1) was found in soil under dwarf pine shrub (6.6-10.3\% of SOC), with less under larch forest (2.6-6.2\% of SOC) and the least in grassland soil (1.7-4.8\% of SOC).
\end{abstract}

\section{Introduction}

Soil plays a crucial role in the life of our planet. The chemical and biological processes that take place in soil regulate the geochemical cycles of most chemical elements, making soil a kind of a buffer and a groundwater "filter" (Keesstra et al., 2012). Soil exchange issues affect the amount of nutrients; hence, the type and quality of soil affect ecosystem productivity (Jonczak, 2013; Brevik et al., 2015). One of the most important features of soil is its structure, as it controls soil water content and air retention capacity, creating a habitat for microorganisms whose activity accelerates nutrient cycling, as well as protecting soil against erosion (Zhang et al., 2013; Zhao et al., 2013). Soil is an immense reservoir of carbon and nitrogen. It is claimed that the carbon content in soil is higher than that in both the terrestrial biosphere and the atmosphere. This makes soil one of the world's most important climate regulators (Brevik et al., 2015).

It is known that land use changes affect soil organic carbon (SOC) stocks. While undergoing natural or human-affected changes, an ecosystem can work as a carbon sink or source, depending on the direction of the conversion. This problem is important and widely discussed in the context of soil degradation, as well as $\mathrm{CO}_{2}$ emissions and from a purely academic point of view (Post and Kwon, 2000; Laganière et al., 2010; Fialho and Zinn, 2012; Corral-Fernández et al., 2013; Lozano-García and Parras-Alcántara, 2013; Batjes, 2014).

Studies on the impact of reforestation on SOC dynamics are particularly interesting as reforestation affects large areas of grassland in mountain areas all over the world (Didier, 2001; Paul et al., 2002; Halliday et al., 2003; Seeber and See- 
ber, 2005; Barua and Haque, 2013). On the other hand, research on SOC storage in mountain regions is rare (Prichard et al., 2000).

In the case of reforested agricultural land, the impact of land use changes on SOC stocks is rather well-known and not called into question. Long-term research has shown that SOC is found to accumulate following reforestation because of increased influx of organic matter (OM) and decelerating decomposition in the forest microclimate (Guo and Gifford, 2002; Murty et al., 2002; Paul et al., 2003; Wang et al., 2011).

In the case of the transition of grassland (pastureland and meadow) into forest, the situation is not clear. In most cases, reforestation is said to cause a decline in SOC stocks in soils found across former pastureland (Alfredsson et al., 1998; Corre et al., 1999; Tate et al., 2000; Guo and Gifford, 2002; Paul et al., 2002), which can be explained by the fact that grasses and herbaceous plants deliver a large amount of biodegradable roots to the soil, which causes the accumulation of OM in humus A horizons in grassland (Oades, 1988). Other analyses have shown that changes in SOC stocks in reforested pastures provide inconclusive results, and the pattern of changes depends largely on local conditions (Murty et al., 2002; Johnson et al., 2003; Laganière et al., 2010, Poeplau and Don, 2013). Debasish-Saha et al. (2014) described higher SOC stocks in soils found under forest than grassland in the subtropical hills of the Lower Himalayas. Laganière et al. (2010) state that in cold humid climates, changes in SOC storage are usually negative (loss of SOC) following reforestation, while in temperate marine climates, changes are clearly positive (SOC accumulation). This trend can be explained by the fact that the slow growth of trees in harsh climate conditions makes the increase in SOC content possible only after a long period of time, while most studies cited by Laganière et al. (2010) were carried out at relatively young plantations. An analysis of SOC changes must take into account the complexity of the carbon cycle in the forest ecosystem - including the accumulation of SOC in soil organic O horizons (Johnson et al., 2003; Seeber and Seeber, 2005; Poeplau and Don, 2013).

Attempts to explain different forms of OM stabilization during accumulation have been undertaken by many researchers (Oades, 1984, 1988; Jastrow, 1996; Six et al., 2001, 2002; Denef et al., 2004; Lützow et al., 2006; Plante et al., 2006; Steward et al., 2008), but in the context of land use, this problem has been usually studied in agricultural soils (Lützow et al., 2002; Denef et al., 2004; Pikul et al., 2007; Barbera et al., 2012; Jaiarree et al., 2014; Srinivasa et al., 2014) or in soils converted from cropland to grassland or forest (Don et al., 2009; Leifeld and Kögel-Knabner, 2005). Some data on differences in mechanisms associated with soil organic matter (SOM) stabilization in forest soils were provided by Laganière et al. (2011). There are few data available for mountain soils, and our understanding of the effect of various environmental factors on SOM turnover is limited
(Leifeld et al., 2009; Budge et al., 2011; Martinsen et al., 2011).

Lützow et al. (2006) point out several mechanisms causing OM stabilization in the soil environment, depending on its form and the rate of linkage with the mineral part of the soil. Particulate organic matter (POM) is claimed to be a potential source of available carbon for decomposers and it is more mineralizable than mineral-associated organic matter (MOM). POM can be protected for a few years because of its primary recalcitrance caused by its specific chemical structure (high lignin, waxes, fats), but its residence time is short. According to radiocarbon measurements, the mean residence time of POM fractions ranges from 1 to 10 years (Lützow et al., 2006), although in mountain soils, it can be as high as 100 years at elevations above $2000 \mathrm{~m}$ because of harsh climate conditions (Leifeld et al., 2009; Budge et al., 2011).

The process that can reduce SOM susceptibility to decomposition is occlusion by aggregation. The primary agents controlling the formation of macroaggregates $(>250 \mu \mathrm{m})$ are stabilization by POM, enmeshment by plant roots and fungal hyphae, as well as in casts and feces promoted by the hydrophobicity of surfaces. Macroaggregation is claimed to be sensitive to farming practices (Oades, 1984; Lützow et al., 2006; van Leeuven et al., 2015). OM turnover is much slower in microaggregates (Lützow et al., 2006) whose OM is protected from enzyme attack by microbial hydrophobic slime and glue as well as by negligible porosity that limits access to bacteria. OM occluded in microaggregates in soils in temperate climates can exist in the soil for about 100 years (vs. 10 years in the case of POM) (Lützow et al., 2006). The residence time of MOM fractions is longer than 100 years, because it is humified, which makes it less available for decomposers (Lützow et al., 2006) and it is also protected against degradation and decomposition by chemical binding; for example, by polyvalent cation bridges in the presence of clay minerals with expandable layer silicates (e.g., smectite, vermiculite, illite) and binding in the presence of metal cations $\left(\mathrm{Ca}^{2+}, \mathrm{Al}^{3+}, \mathrm{Fe}^{3+}\right.$ and heavy metals), e.g., by complexation (Lützow et al., 2006; Grünberg et al., 2013; Jindaluang et al., 2013). According to Leifeld et al. (2009), the mean residence time for MOM fractions in alpine soils ranges between 200 and 2200 years, depending on elevation and soil depth. The residence time of a passive pool of OM bound to clay minerals depends on the clay mineralogy in a particular soil (Bruun et al., 2015).

The aim of our research was to determine SOC sequestration in calcareous shallow soils (Leptosols) in a renaturalized area in Jaworzynka Valley (Tatra Mts.) as well as to estimate OM distribution in soil physical fractions with respect to different types of land use. We are not aware of any studies focused on SOC sequestration having been conducted in soils formed on carbonate parent material and containing carbonates from the surface of the mineral part of the soil profile. 

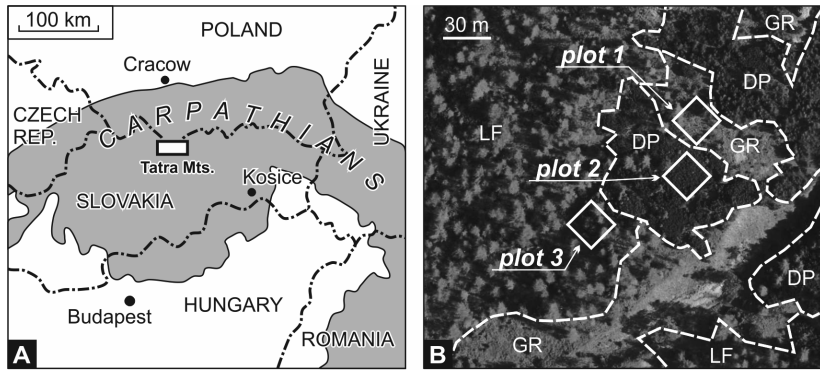

Figure 1. Location of the study area: (a) Tatra Mountains in the Carpathian mountain chain; (b) aerial photographs of the study area in Jaworzynka Valley with marked research plots: GR mountain grassland (high mountain calcareous grassland: Carici sempervirentis-Festucetum tatrae association), DP - thickets of dwarf pine Pinetum mughi, LF - open (sparse) larch (Larix sp.) forest with a dense cover of grass Calamagrostis sp. on the forest floor.

\section{Methods}

\subsection{Study area and experimental design}

Our research study was conducted in Jaworzynka Valley in the Tatra Mts. in southern Poland - a mountain range located in central Europe and belonging to the Alpine mountain system (Fig. 1a, b). The process of reforestation and afforestation provides an opportunity to see how SOC accumulation has changed in calcareous soils in the Tatra Mts. due to different types of land use. Reforestation started in the Tatras in the 1960s when sheep grazing was banned in the interest of nature conservation. Since that time, some abandoned pastureland has undergone natural succession, while some has been afforested as part of a major government afforestation program in Poland.

Animals (mainly sheep) had grazed in Jaworzynka Valley since the 16th century (Fig. 2). Grazing was banned in 1963. The soils on the sides of the valley became heavily eroded. In light of the risk of further erosion, dwarf pine shrub (Pinetum mughi) and larch (Larix sp.) forest were planted (1962-1963). Afforestation efforts stopped in 1970. Some places have been left as mountain grasslands (clearings). Jaworzynka Valley now features a mosaic of the aforementioned plant communities (Figs. 1b, 3). No forest management work has been done since the ban on grazing and the start of afforestation, and all plots undergo natural succession as part of a national park.

The valley is made up of dolomitic limestone (Anisian, Ladinian) (Sokołowski and Jaczynowska, 1979). The mean annual air temperature in the study area (data for the nearest station: Hala Gasienicowa) is $2.4^{\circ} \mathrm{C}$. The mean annual temperature of the warmest month (August) is $10.8^{\circ} \mathrm{C}$ (min. $-4.1^{\circ} \mathrm{C}$; max. $\left.17.6^{\circ} \mathrm{C}\right)$. The mean annual temperature of the coldest month (February) is $-5.3^{\circ} \mathrm{C}$ (min. $-21.4^{\circ} \mathrm{C}$; max.

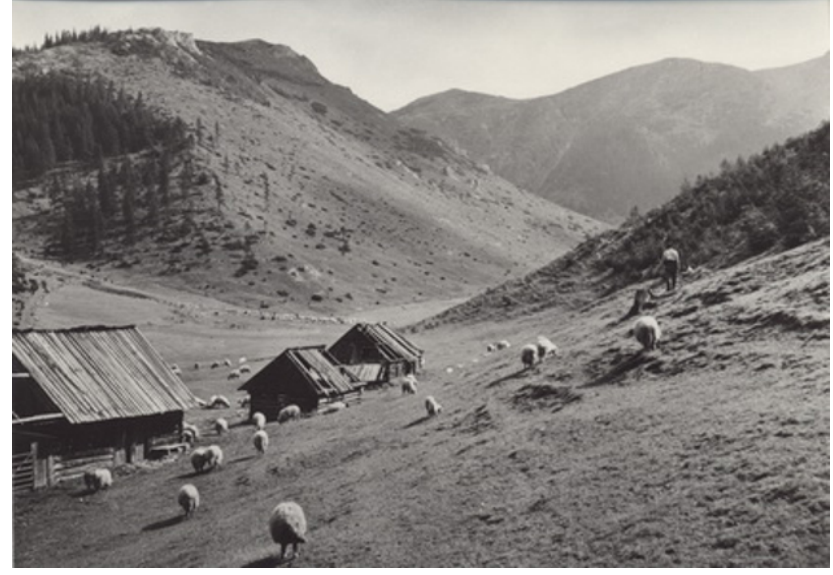

Figure 2. Sheep grazing in Jaworzynka Valley; shepherds' huts are visible (photo archive - Tatra Documentation Center, Tatra National Park, Zakopane, Poland).

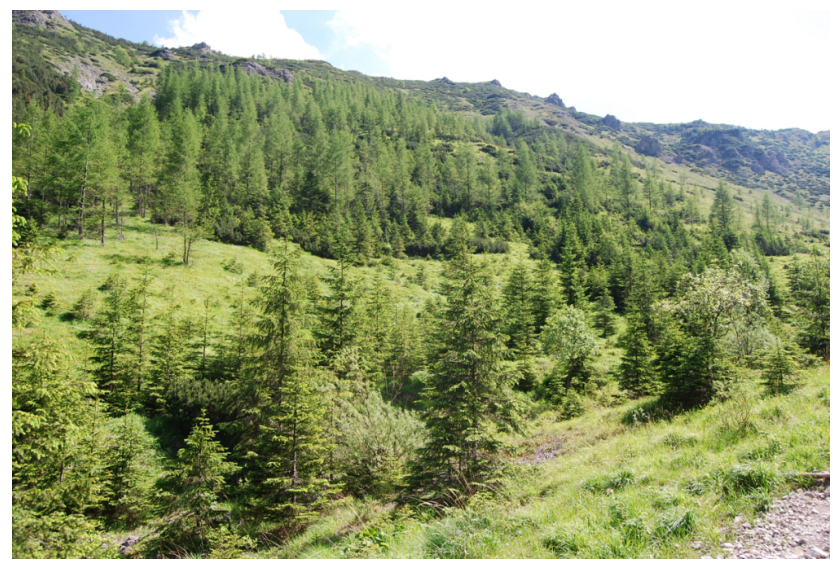

Figure 3. Present-day view of Jaworzynka Valley.

$7.2^{\circ} \mathrm{C}$ ). The valley's mean annual precipitation is $1661 \mathrm{~mm}$ (Błażejczyk et al., 2013).

The research study was conducted on three plots $(30 \mathrm{~m} \times 30 \mathrm{~m})$ located close (Fig. 1b) to each other to avoid differences connected with slope position and exposure, which can affect SOC stock variability (Fernández-Romero et al., 2014) as well as geological and soil heterogeneity that can affect SOC stocks and forms of OM (Baldock and Skjemstad, 2000; Parras-Alcántara et al., 2014). Plot no. 1 represented a mountain grassland (high mountain calcareous grassland: Carici sempervirentis-Festucetum tatrae association). Plot no. 2 represented thickets of dwarf pine Pinetum mughi. Plot no. 3 represented sparse larch (Larix sp.) forest (ca. 400 trees ha $^{-1}$ ) with a dense cover of grass Calamagrostis sp. on the forest floor (Fig. 4). The three plots were located at an elevation between 1200 and $1220 \mathrm{~m}$ (location: $49^{\circ} 15^{\prime} 32^{\prime \prime} \mathrm{N}, 19^{\circ} 59^{\prime} 35^{\prime \prime} \mathrm{E}$ ) on a uniformly inclined slope (linear mountain side slopes) of $25^{\circ} \mathrm{SW}$. 


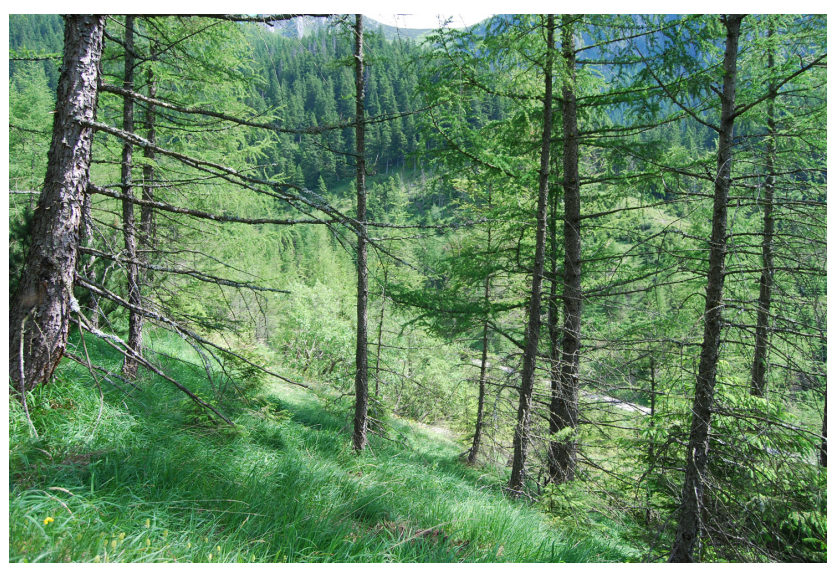

Figure 4. Open larch (Larix sp.) forest with a dense cover of grass Calamagrostis sp. on the forest floor - plot no. 3 .

\subsection{Field methods}

Nine soil profiles were excavated in each plot; therefore, the soil material was collected from 27 pits. Soil profiles were excavated down to the lithic contact and described according to Schoeneberger et al. (2002). A reference profile was selected at each study site - the soil profile nearest to the central point of the plot (Table 1).

Unlike in the case of many other research studies, it was decided to collect samples from the genetic horizons of the soil, and not from the intervals. Organic O horizons are well-developed in mountain soils (Kubiena, 1953; Drewnik, 2006); therefore, it is necessary to take into account the boundary between the organic $\mathrm{O}$ horizon and the A horizon in research focused on the mechanisms of OM storage in soil.

One large (mineral sample - approx. $2 \mathrm{~kg}$, organic sample - approx. $0.3 \mathrm{~kg}$; moist), representative bulk sample was collected from each studied genetic soil horizon, then placed in sterile polyethylene bags. In addition, undisturbed soil samples were collected from the reference soil profiles in order to determine the bulk density of fine soils. In this case, due to a very large quantity of stone and gravel, a steel frame $(20 \times 20 \mathrm{~cm})$ was used to obtain a large sample in the form of a rectangular prism, with a volume ranging from 4000 to $8000 \mathrm{~cm}^{3}$, depending on the horizon. The studied soils were classified according to the WRB system (IUSS Working Group WRB, 2007).

\subsection{Laboratory methods}

Bulk soil samples taken from A horizons and mineral B horizons were air-dried, gently crushed using a wooden rolling pin, and sieved using a $2 \mathrm{~mm}$ sieve. Live roots were removed. Soil samples from $\mathrm{O}$ horizons were milled after the living parts of plants in the samples had been removed.

Stone and gravel content (particles $>2 \mathrm{~mm}$ ) was determined by weighing. Bulk density of fine soil (BD(f)) (mass volume ${ }^{-1}$ ) was calculated according to Don et al. (2007) as follows:

$$
\mathrm{BD}(\mathrm{f})=\frac{\text { mass }_{\text {sample }}-\text { mass }_{\text {particles }>2 \mathrm{~mm}}}{\text { volume }_{\text {sample }}-\frac{\text { mass particles }>2 \mathrm{~mm}_{\text {density }} \text { particles }>2 \mathrm{~mm}}{}} .
$$

Texture was determined by wet sieving (sand fractions) and the hydrometer method (silt and clay fractions) (Gee and Bauder, 1986). The concentration of total carbon (TC) and nitrogen $(\mathrm{N})$ was determined by dry combustion gas chromatography using a CHNS analyzer (Elementar vario MI$\mathrm{CRO}$ cube elemental analyzer). $\mathrm{CO}_{2}$ content obtained from carbonates $\left(\mathrm{CO}_{2 \text { (carb) }}\right)$ was determined using the volumetric calcimeter method. Each sample's $\mathrm{pH}$ was measured in deionized water (1:2.5 soil / water ratio) (Thomas, 1996). Soil color was described in the moist state using Munsell Soil Color Charts (Oyama and Takehara, 2002).

SOC was calculated by subtracting inorganic carbon (SIC - carbon from $\mathrm{CO}_{2 \text { (carb) }}$ ) from TC. SOC stocks were calculated according to Don et al. (2007), as follows:

$\mathrm{SOC}=\sum_{t=0}^{n} \mathrm{BD}(\mathrm{f}) \times \mathrm{SOC} \times \mathrm{depth}_{\text {volume }}$.

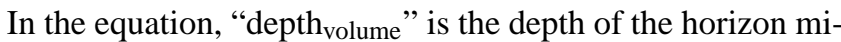
nus the volume of particles $\emptyset>2 \mathrm{~mm}$. This calculation excludes particles $\varnothing>2 \mathrm{~mm}$ as they are not a component of bulk density.

Physical fractionation of the soil was carried out according to the Leifeld and Kögel-Knabner (2005) method to obtain several OM fractions: free light particulate fraction (POM LF1), light fraction occluded in macroaggregates (POM LF2), residual fraction occluded in microaggregates (ROM), and MOM: MOM fraction outside water-stable aggregates (MOM FF1), MOM fraction inside macroaggregates released after their disruption (MOM FF2), and MOM fraction inside microaggregates released after their disruption (MOM FF3). A $30 \mathrm{~g}$ sample of air-dried soil $(<2 \mathrm{~mm})$ was immersed in deionized water on a $20 \mu \mathrm{m}$ mesh. After $5 \mathrm{~min}$, the material was gently sieved to obtain a mineral fraction outside water-stable aggregates $<20 \mu \mathrm{m}$ (FF1). The sieved material was air-dried at $40^{\circ} \mathrm{C}$ and weighed. It was then transferred into a $100 \mathrm{~mL}$ centrifuge beaker and sodium polytungstate solution $\left(1.8 \mathrm{~g} \mathrm{~cm}^{-3}\right)$ was added. The resulting material was gently stirred, left for $10 \mathrm{~min}$ to settle, and centrifuged for $10 \mathrm{~min}(2320 \mathrm{~g})$.

POM LF1 was decanted and washed with deionized water using a $20 \mu \mathrm{m}$ mesh. The residual soil material was dispersed ultrasonically (Sonics 750 ) with an energy of $22 \mathrm{~J} \mathrm{~mL}^{-1}$ to break down macroaggregates. The dispersed soil was sieved at $20 \mu \mathrm{m}$ mesh to obtain a mineral fraction $<20 \mu \mathrm{m}$ inside macroaggregates (FF2), dried, and POM LF2 was separated as described for POM LF1. The residual soil material was dispersed ultrasonically with an energy of $450 \mathrm{~J} \mathrm{~mL}^{-1}$ to break down microaggregates. The material was sieved using a $20 \mu \mathrm{m}$ mesh to obtain a residual fraction (ROM) and 
Table 1. Basic properties of reference soil profiles.

\begin{tabular}{|c|c|c|c|c|c|c|c|c|c|c|c|}
\hline Horizon & $\begin{array}{r}\text { Depth } \\
(\mathrm{cm})\end{array}$ & $\begin{array}{c}\text { Particles }>2 \mathrm{~mm} \\
(\%)\end{array}$ & $\begin{array}{l}\text { Color } \\
\text { (moist) }\end{array}$ & Texture & $\begin{array}{c}\mathrm{BD}(\mathrm{f})^{1} \\
\left(\mathrm{Mg} \mathrm{m}^{-3}\right)\end{array}$ & $\begin{array}{r}\mathrm{CO}_{2 \text { (carb) }}{ }^{2} \\
\quad\left(\mathrm{~g} \mathrm{~kg}^{-1}\right)\end{array}$ & $\begin{array}{c}\mathrm{TC}^{3} \\
\left(\mathrm{~g} \mathrm{~kg}^{-1}\right)\end{array}$ & $\begin{array}{r}\mathrm{SOC}^{4} \\
\left(\mathrm{~g} \mathrm{~kg}^{-1}\right)\end{array}$ & $\begin{array}{r}\mathrm{N}^{5} \\
\left(\mathrm{~g} \mathrm{~kg}^{-1}\right)\end{array}$ & $\begin{array}{c}\mathrm{pH} \\
\left(\mathrm{H}_{2} \mathrm{O}\right)\end{array}$ & $\mathrm{C} / \mathrm{N}^{6}$ \\
\hline \multicolumn{12}{|c|}{ Profile no. 1; plot no. 1; mountain meadow - grassland; Rendzic Hyperskeletic Leptosol (Humic, Eutric) } \\
\hline A1 & $0-15$ & 58 & $10 \mathrm{YR} 2 / 2$ & silt loam & 0.26 & 301.1 & 143.3 & 62.0 & 5.0 & 7.57 & 12.4 \\
\hline $\mathrm{A} 2$ & $15-32$ & 81 & 10YR2/2 & silt loam & 0.18 & 262.4 & 133.6 & 62.7 & 4.9 & 7.67 & 12.8 \\
\hline $\mathrm{B}$ & $32-42$ & 90 & 10YR4/4 & silt loam & 0.43 & 334.0 & 118.1 & 27.9 & 2.5 & 7.87 & 11.2 \\
\hline \multicolumn{12}{|c|}{ Profile no. 2; plot no. 2; dwarf pine shrub (Pinetum mughi); Folic Hyperskeletic Leptosol (Calcaric, Humic) } \\
\hline Oi1 & $0-10$ & 0 & \multirow{2}{*}{\multicolumn{2}{|c|}{$\begin{array}{l}\text { organic material } \\
\text { organic material }\end{array}$}} & 0.02 & 0.0 & 477.9 & 477.9 & 10.8 & 4.30 & 44.3 \\
\hline Oi2 & 10-20 & 8 & & & 0.03 & 5.1 & 470.4 & 469.0 & 11.4 & 5.11 & 41.1 \\
\hline A1 & $20-25$ & 45 & 10YR2/1 & silt loam & 0.18 & 249.3 & 147.2 & 79.9 & 6.0 & 7.47 & 13.3 \\
\hline A2 & $25-45$ & 63 & 10YR2/1 & silt loam & 0.19 & 306.0 & 138.7 & 56.1 & 4.5 & 7.60 & 12.5 \\
\hline A3 & $45-50$ & 70 & 10YR2/1 & silt loam & 0.19 & 308.1 & 135.5 & 52.3 & 4.5 & 7.66 & 11.6 \\
\hline \multicolumn{12}{|c|}{ Profile no. 3; plot no. 3; larch (Larix sp.) forest; Rendzic Hyperskeletic Leptosol (Humic, Eutric) } \\
\hline Oi & $0-2$ & 0 & \multicolumn{2}{|c|}{ organic material } & 0.03 & 33.5 & 436.4 & 427.3 & 11.2 & 6.35 & 38.2 \\
\hline A1 & $2-12$ & 56 & $10 \mathrm{YR} 3 / 2$ & silt loam & 0.37 & 264.2 & 124.6 & 53.3 & 4.3 & 7.58 & 12.4 \\
\hline A2 & $12-22$ & 58 & $10 \mathrm{YR} 3 / 2$ & silt loam & 0.39 & 294.8 & 121.2 & 41.6 & 2.7 & 7.72 & 15.4 \\
\hline B & $22-30$ & 77 & $10 \mathrm{YR} 4 / 4$ & silt loam & 0.40 & 396.5 & 116.5 & 9.4 & 0.8 & 7.80 & 11.8 \\
\hline
\end{tabular}

${ }^{1}$ bulk density of the fine soil, ${ }^{2} \mathrm{CO}_{2 \text { (carb) }}-\mathrm{CO}_{2}$ from carbonates; ${ }^{3}$ total carbon; ${ }^{4}$ soil organic carbon; ${ }^{5}$ total nitrogen; ${ }^{6} \mathrm{SOC} / \mathrm{N}$ ratio

obtain a mineral fraction $<20 \mu \mathrm{m}$ inside macroaggregates (FF3). The mineral fractions $<20 \mu \mathrm{m}$ (FF1, FF2, FF3) were collected after each dispersion step, washed by centrifugation, and weighed. The mass of these fractions relative to the total mass of the $<20 \mu \mathrm{m}$ fraction was taken as a sign of soil aggregate stability.

The concentration of $\mathrm{TC}, \mathrm{N}$ and $\mathrm{CO}_{2 \text { (carb) }}$ as well as the content of particles $\emptyset>2 \mathrm{~mm}$ were determined for $106 \mathrm{sam}$ ples from all the studied soil profiles, while the texture, bulk density, $\mathrm{pH}$, and $\mathrm{OM}$ fractionation were determined for samples from reference profiles (Table 1). Only material from A horizons was fractioned, because the soil material from O horizons was poorly decomposed without signs of mixing with mineral matter.

In this study, it was considered justified to use descriptive statistics for presenting the value structure of variables resulting from measurements. The use of statistical inference to assess the significance of differences between the characteristics of three different sampled areas was not considered warranted, given the inadequate number of samples $(3 \times 9$ profiles).

\section{Results}

\subsection{Soil morphology, physical and chemical properties of soils}

According to the WRB system (IUSS Working Group WRB, 2007), reference profiles no. 1 and 3 were classified as Rendzic Hyperskeletic Leptosols (Humic, Eutric), while profile no. 2 was classified as a Folic Hyperskeletic Leptosol (Calcaric, Humic) (Table 1).
O horizons (Oi) in profiles no. 2 and 3 had a thickness of 20 and $2 \mathrm{~cm}$, respectively. The content of $\varnothing>2 \mathrm{~mm}$ particles increased with depth from 0 to $70-90 \%$ at a depth of $30 \mathrm{~cm}$. Fine soil had a dark color in the range of 10YR 2-4/1-4 and silt loam texture (Table 1). The studied soils were characterized by a very low bulk density of approx. $0.02-0.03 \mathrm{Mg} \mathrm{m}^{-3}$ in $\mathrm{O}$ horizons and approx. $0.18-0.43 \mathrm{Mg} \mathrm{m}^{-3}$ in A horizons and $\mathrm{B}$ horizons. Carbonates were found to be present in the fine soils. Carbonate content was very low $\left(0.00-33.5 \mathrm{~g} \mathrm{~kg}^{-1}\right.$ of carbonate $\mathrm{CO}_{2}$ ) in organic $\mathrm{O}$ horizons and increased with depth from $250 \mathrm{~g} \mathrm{~kg}^{-1}$ of carbonate $\mathrm{CO}_{2}$ in A horizons to $300-400 \mathrm{~g} \mathrm{~kg}^{-1}$ of carbonate $\mathrm{CO}_{2}$ in $\mathrm{B}$ horizons (Table 1). Soil $\mathrm{pH}$ values change with depth. The $\mathrm{pH}$ value range measured in distilled water was 4.3-5.1 (profile no. 2) and 6.3 (profile no. 3) in O horizons, 7.5-7.7 in A horizons, and approx. 7.8 in B horizons (Table 1).

\subsection{SOC concentration, SOC stock, and C / N ratio}

Mean SOC concentration was the highest in $\mathrm{O}$ horizons $\left(465.3 \mathrm{~g} \mathrm{~kg}^{-1}\right.$ in soils under dwarf pine and $351.7 \mathrm{~g} \mathrm{~kg}^{-1}$ in soils under larch forest), medium in A horizons (56.8$\left.65.5 \mathrm{~g} \mathrm{~kg}^{-1}\right)$, and the lowest in $\mathrm{B}$ horizons $\left(15.9 \mathrm{~g} \mathrm{~kg}^{-1}\right.$ under larch forest and $21.7 \mathrm{~g} \mathrm{~kg}^{-1}$ under grassland) (Table 2).

The SOC stock was $63.5 \mathrm{Mg} \mathrm{ha}^{-1}$ in soil under larch forest, $47.5 \mathrm{Mg} \mathrm{ha}^{-1}$ in grassland soil, and $42.9 \mathrm{Mg} \mathrm{ha}^{-1}$ in soil under dwarf pine shrub (Fig. 5). In all plots, SOC was accumulated mainly in the mineral part of soil (A horizons and B horizons): $100 \%$ of SOC in grassland, $94 \%$ in larch forest, and $67 \%$ in soil under dwarf pine.

The $\mathrm{C} / \mathrm{N}$ ratio varies depending on the type of soil horizon. It was 41.9 in the $\mathrm{O}$ horizon in soils under dwarf pine shrub, and 28.5 in soils under larch forest, and ranged from 
Table 2. The concentration of TC, SIC, SOC, and C / N ratio in analyzed soils - mean values (standard deviation in brackets).

\begin{tabular}{llrrrrr}
\hline \multirow{2}{*}{ Plot } & & & $\mathrm{TC}^{2}$ & $\mathrm{SIC}^{3}$ & \multicolumn{2}{c}{$\mathrm{SOC}^{4}$} \\
\cline { 5 - 6 } & Type of soil horizon & $n^{1}$ & $\left(\mathrm{~g} \mathrm{~kg}^{-1}\right)$ & $\left(\mathrm{g} \mathrm{kg}^{-1}\right)$ & $\left(\mathrm{g} \mathrm{kg}^{-1}\right)$ & $\mathrm{C} / \mathrm{N} \mathrm{ratio}^{5}$ \\
\hline \multirow{2}{*}{ Mountain grassland } & Humus A horizons & 18 & $135.7(7.4)$ & $76.5(7.6)$ & $59.2(12.6)$ & $12.9(1.0)$ \\
& Mineral B horizon & 9 & $124.4(5.9)$ & $92.7(29.3)$ & $21.7(9.5)$ & $10.7(1.7)$ \\
\hline \multirow{2}{*}{ Dwarf pine, Pinetum mughi } & Organic O horizons & 13 & $467.3(37.6)$ & $2.1(5.5)$ & $465.3(42.7)$ & $41.9(7.9)$ \\
& Humus A horizons & 20 & $136.7(25.0)$ & $71.3(18.1)$ & $65.5(34.1)$ & $13.0(2.3)$ \\
\hline \multirow{2}{*}{ Larch (Larix sp.) forest } & Organic O horizons & 20 & $362.8(72.4)$ & $11.1(9.0)$ & $351.7(80.0)$ & $28.5(6.6)$ \\
& Humus A horizons & 18 & $120.3(10.4)$ & $63.4(13.6)$ & $56.8(15.6)$ & $12.8(1.0)$ \\
& Mineral B horizon & 8 & $117.1(7.4)$ & $101.2(13.2)$ & $15.9(7.8)$ & $13.5(1.3)$ \\
\hline
\end{tabular}

${ }^{1}$ number of samples; ${ }^{2}$ total carbon; ${ }^{3}$ inorganic carbon (carbon from $\left.\mathrm{CO}_{2(\mathrm{carb})}\right) ;{ }^{4}$ soil organic carbon; ${ }^{5} \mathrm{SOC} / \mathrm{N}$ ratio

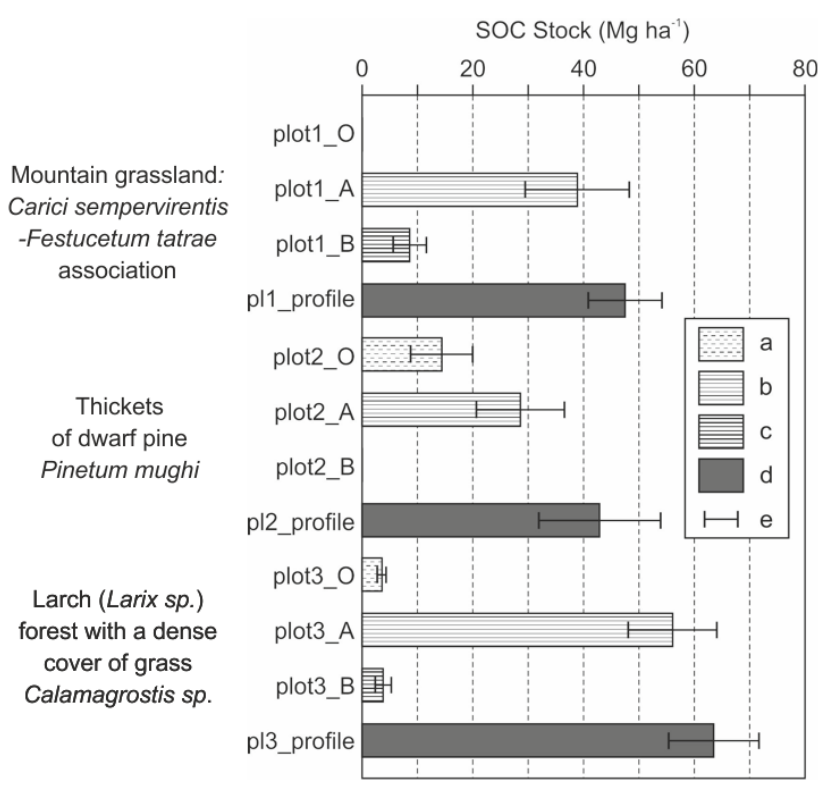

Figure 5. SOC stock for particular plots (data from 27 soil profiles). a: SOC stock in organic O horizons, b: SOC stock in humus A horizons, c: SOC stock in mineral B horizons, d: SOC stock in the entire soil profile, and e: standard deviation.

10.7 to 13.5 in A horizons and B horizons in all the studied soils (Table 2).

\subsection{Characteristics of individual fractions}

The mass of the FF2 fraction accounted for more than $60 \%$ of the $<20 \mu \mathrm{m}$ fraction total in soils under dwarf pine shrub and larch forest and more than $52 \%$ of the $<20 \mu \mathrm{m}$ fraction total in soil under grassland (Table 3). The mass of the FF3 fraction of the $<20 \mu \mathrm{m}$ fraction total ranged from 27.9 to $31.6 \%$ in soil under dwarf pine shrub and larch forest, and from 43.6 to $44.8 \%$ in soil under grassland. The mass of the FF1 fraction of the $<20 \mu \mathrm{m}$ fraction total was the lowest in all the studied soil profiles (accounted for $0.9 \%$ in the A2 horizon in grassland soil to $9.6 \%$ in the A1 horizon in soil under dwarf pine).

In A horizons, SOC content in MOM fractions accounted for 67.6 to $85.8 \%$ of total SOC, while in POM + ROM fractions, it ranged from 12.4 to $32.4 \%$ of total SOC (Table 4 ).

The SOC concentration of the two POM fractions (POM LF1 and POM LF2) ranged from 227.4 to $308.3 \mathrm{~g} \mathrm{SOC} \mathrm{kg}^{-1}$ (Table 4). The highest content of SOC of POM LF1 was found in the A1 horizon of soil under dwarf pine shrub ( $10.3 \%$ of SOC), and the lowest in the A2 horizon in soil under grassland (1.7\% of SOC). SOC content of POM LF2 was the highest in the A1 horizon in soil under dwarf pine shrub (18.3\% of SOC) and the lowest in the A2 horizon in soil under larch forest (5.3\% of SOC) (Table 4). SOC concentration in MOM fractions ranged from 35.6 to $97.1 \mathrm{~g} \mathrm{SOC} \mathrm{kg}^{-1}$. The SOC content in MOM FF2 was the highest among all MOM fractions, and ranged from $37.9 \%$ of SOC in the A1 horizon in grassland soil to $59.2 \%$ of SOC in the A2 horizon soil under dwarf pine shrub. SOC content in MOM FF3 accounted for $15.3 \%$ of SOC in the A2 horizon under larch forest to $27.1 \%$ of SOC in the A1 horizon in soil under grassland (Table 4). SOC content in MOM FF1 was the lowest among all MOM fractions and accounted for $0.5 \%$ of SOC in soil under grassland to $3.8 \%$ of SOC in soil under dwarf pine shrub.

The $\mathrm{C} / \mathrm{N}$ ratio varied depending on the $\mathrm{OM}$ fraction from 17.1 to 34.0 in POM fractions and from 7.2 to 11.5 in MOM fractions (Table 5).

\section{Discussion}

\subsection{Soil properties}

The studied soils possessed characteristics of soils formed on carbonate rock in a fairly harsh mountain climate (Jenny, 1930; Kubiena, 1953; Skiba, 1983). The soils had a high SOC concentration in A horizons, and thick O horizons occurred in soils formed under dwarf pine shrub (Bochter and Zech, 1985; Drewnik, 2006). The studied soils had a high 
Table 3. Fraction of particles $<20 \mu \mathrm{m}$ released after wet sieving and ultrasonification to the release of total fine fraction (FF).

\begin{tabular}{|c|c|c|c|c|}
\hline \multirow[b]{3}{*}{ Horizon } & \multirow{3}{*}{$\begin{array}{l}\text { Depth } \\
(\mathrm{cm})\end{array}$} & \multirow[b]{2}{*}{$\begin{array}{l}\text { Wet sieving } \\
\text { (FF1 fraction) }\end{array}$} & \multicolumn{2}{|c|}{ Ultrasonification } \\
\hline & & & $\begin{array}{c}22 \mathrm{~J} \mathrm{~mL}^{-1} \\
\text { (FF2 fraction) }\end{array}$ & $\begin{array}{c}450 \mathrm{~J} \mathrm{~mL}^{-1} \\
\text { (FF3 fraction) }\end{array}$ \\
\hline & & \multicolumn{3}{|c|}{$(\%)$} \\
\hline \multicolumn{5}{|c|}{ Profile no. 1; plot no. 1; mountain meadow - grassland; Rendzic Hyperskeletic Leptosol (Humic, Eutric) } \\
\hline A1 & $0-15$ & 4.2 & 52.3 & 43.6 \\
\hline $\mathrm{A} 2$ & $15-32$ & 0.9 & 54.3 & 44.8 \\
\hline \multicolumn{5}{|c|}{ Profile no. 2; plot no. 2; dwarf pine shrub (Pinetum mughi); Folic Hyperskeletic Leptosol (Calcaric, Humic) } \\
\hline A1 & $20-25$ & 9.6 & 59.5 & 30.9 \\
\hline $\mathrm{A} 2$ & $25-45$ & 9.4 & 61.8 & 28.8 \\
\hline A3 & $45-50$ & 7.6 & 64.5 & 27.9 \\
\hline \multicolumn{5}{|c|}{ Profile no. 3; plot no. 3; larch (Larix sp.) forest; Rendzic Hyperskeletic Leptosol (Humic, Eutric) } \\
\hline A1 & $2-12$ & 7.2 & 61.3 & 31.6 \\
\hline $\mathrm{A} 2$ & $12-22$ & 7.6 & 63.6 & 28.7 \\
\hline
\end{tabular}

Table 4. Soil organic carbon (SOC) in fractions.

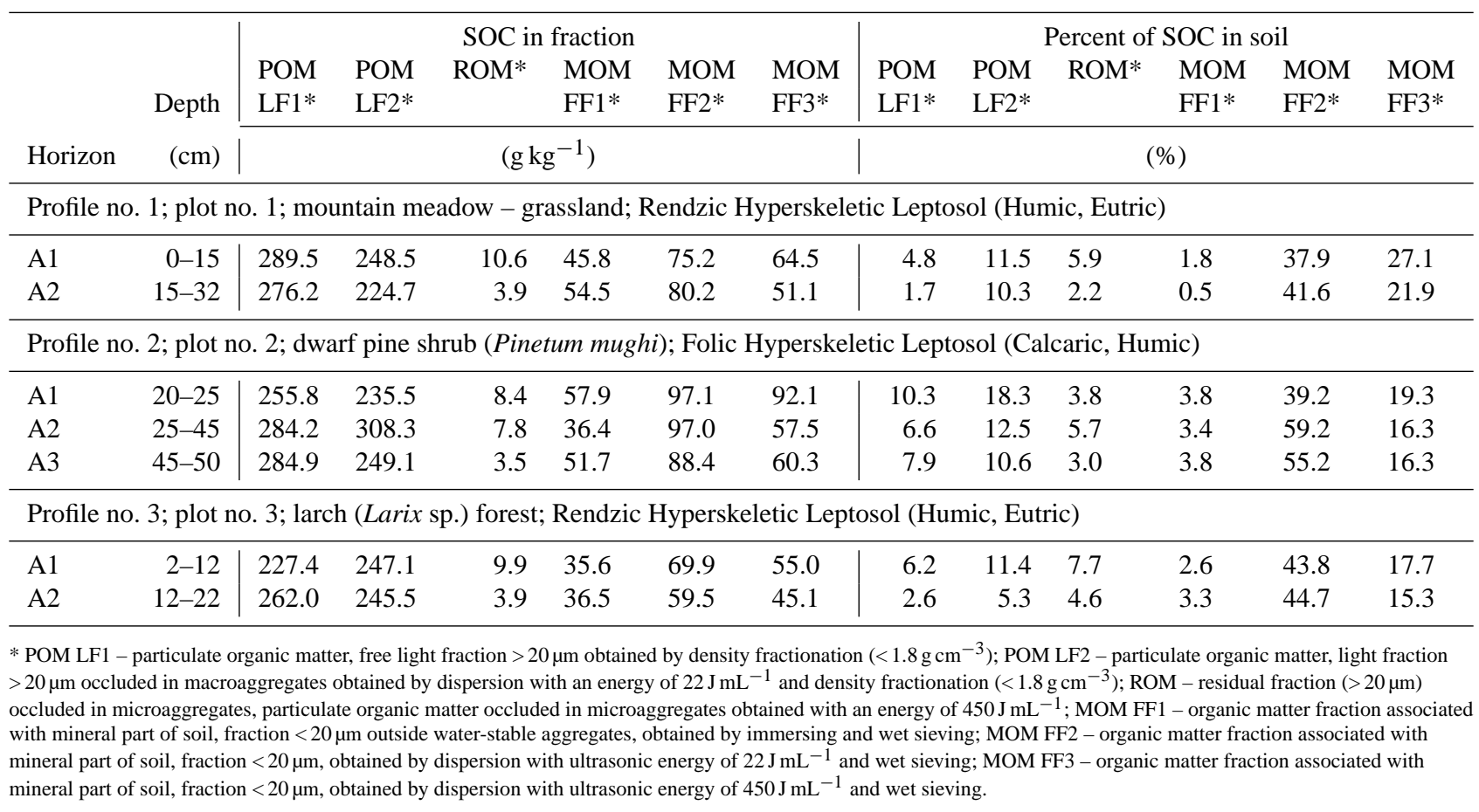

$\mathrm{pH}$ due to their calcareous parent material despite the humid climate in the region (Table 1). However, despite their typicality, these soils were much shallower and had a larger content of stone than soils formed under comparable conditions in the Tatra Mts. (Skiba, 1983; Miechówka, 2000; Drewnik, 2006), which is most likely due to the fact that these soils occur on slopes, which are subject to strong erosion caused by animal grazing. Very low bulk density occurred in $\mathrm{O}$ horizons in comparison with other results from mountainous soils (Kammer et al., 2009; Budge et al., 2011; Martinsen et al., 2011) and this can be explained by the fact, that these horizons are built of relatively fresh, loose material, with no signs of advanced humification. 
Table 5. C / $\mathrm{N}$ ratio in fractions.

\begin{tabular}{|c|c|c|c|c|c|c|c|}
\hline Horizon & Depth $(\mathrm{cm})$ & POM LF1* & POM LF2* & $\mathrm{ROM}^{*}$ & MOM FF1* & MOM FF2* & MOM FF3* \\
\hline \multicolumn{8}{|c|}{ Profile no. 1; plot no. 1; mountain meadow - grassland; Rendzic Hyperskeletic Leptosol (Humic, Eutric) } \\
\hline A1 & $0-15$ & 30.2 & 26.2 & 26.5 & 7.3 & 9.6 & 9.4 \\
\hline $\mathrm{A} 2$ & $15-32$ & 34.1 & 18.7 & 9.8 & 8.7 & 9.8 & 8.8 \\
\hline \multicolumn{8}{|c|}{ Profile no. 2; plot no. 2; dwarf pine shrub (Pinetum mughi); Folic Hyperskeletic Leptosol (Calcaric, Humic) } \\
\hline $\mathrm{A} 1$ & $20-25$ & 27.8 & 19.3 & 21.0 & 9.1 & 9.3 & 11.5 \\
\hline $\mathrm{A} 2$ & $25-45$ & 31.6 & 23.0 & 4.1 & 7.3 & 10.4 & 10.1 \\
\hline A3 & $45-50$ & 33.5 & 17.1 & 2.9 & 7.2 & 8.8 & 9.6 \\
\hline \multicolumn{8}{|c|}{ Profile no. 3; plot no. 3; larch (Larix sp.) forest; Rendzic Hyperskeletic Leptosol (Humic, Eutric) } \\
\hline A1 & $2-12$ & 29.9 & 21.3 & 4.0 & 7.6 & 9.0 & 8.6 \\
\hline A2 & $12-22$ & 34.0 & 19.5 & 3.9 & 7.2 & 8.4 & 8.5 \\
\hline
\end{tabular}

* explanation in Table 4

\subsection{Land use effects on soil morphology and SOC stocks}

The effect of vegetation type in the Jaworzynka Valley can be observed in terms of changes in OM content in the soil. The greatest accumulation of SOC was observed in soils under larch forest, and less accumulation was observed in soils under grassland and under dwarf pine shrub (Fig. 5). The highest stock of SOC sequestered in the A horizon in soil under larch forest can be explained by the nature of local vegetation. The larch forest was sparse with a dense cover of Calamagrostis sp. on its floor (Fig. 4). No biomass measurements were done as part of the study, but it may be assumed that tall Calamagrostis sp. grass supplies a higher amount of plant tissue to the soil than short xerothermic grassland plants do. Guzman et al. (2014) found that after 3 years of the reclamation of mining area soils using tall prairie grasses, these soils had received significantly more biomass than soils reclaimed using cool-season forage grass. In the Jaworzynka Valley, the relatively higher SOC stock in larch forest (Fig. 5) can be also explained by a specific forest microclimate affecting the composition of forest floor species and OM decomposition rates and the fall of needles, which does not occur in grassland areas (cf. Kim, 2000; Seeber and Seeber, 2005; Rigueiro-Rodríguez et al., 2012). Soils covered with larch forest are not studied very often; however, the SOC stock in Jaworzynka Valley soils in plot no. 3 was in the range given for soils found in larch forests (formerly agriculturally used Luvisols) in China (Wang et al., 2011).

While the SOC stock was quite uniform throughout the entire soil profile in soils found under dwarf pine shrub as well as soils under grassland, it was grassland soils that had a significantly higher amount of SOC sequestered in the studied A horizon rather than dwarf pine shrub soils (Fig. 5). This finding is partly consistent with other newer results cited by Laganière et al. (2010) and Poeplau and Don (2013), pro- viding evidence of decreasing SOC stocks following grassland reforestation in the first several years after the conversion from pastureland to grassland. This is most likely due to certain constraints placed on the delivery of very rapidly decomposable grass roots in forest ecosystems in comparison with grassland ecosystems (Oades, 1988).

In coniferous forests ecosystems, thick $\mathrm{O}$ horizons develop (Table 1) as a result of a large amount of litter supplied to the soil as well as a specific forest microclimate and acidification caused as a result of needle decomposition (Bochter and Zech, 1985; Seeber and Seeber, 2005; Drewnik, 2006). The development of O horizons can rarely offset SOC depletion caused by the limited supply of grass roots (Kammer et al., 2009). In the studied soils under dwarf pine shrub, the SOC stock in the $\mathrm{O}$ horizon comprised only one-third of the entire SOC stock despite its substantial thickness, which is similar to the results obtained in forest soils in the Stołowe Mts. in southwestern Poland (Gałka et al., 2014).

The relatively small SOC stock in dwarf pine shrub soils may be the result of the fact that it is a relatively young plant community and large amounts of $\mathrm{OM}$ - derived from the roots of dead trees, as observed by Debasish-Saha et al. (2014) in the soils of the Lower Himalayan hills - have not yet appeared.

The SOC stock determined for individual plots in our study area (Fig. 5) was significantly lower than that found in similar mountain environments in the temperate climate zone (Kammer et al., 2009, Gałka et al., 2014). The most important reason for the relatively small SOC stock was the small depth of the soil and a very large number of $\varnothing>2 \mathrm{~mm}$ particles (Table 1). This produced a low SOC stock despite a high content of these elements in the local soil mass (fine particles) (Table 2). Studies on SOC stocks have not been carried out in the Tatra Mts. so far, but results obtained by Skiba (1983) and Miechówka (2000) indicate that soils developed on calcareous parent material and under similar con- 
ditions are characterized by a similar or higher concentration of SOC, greater thickness as well as a smaller number of $\varnothing>2 \mathrm{~mm}$ particles, which allows to suppose that the SOC stock would also be higher in typical Tatra soils than that in the studied soils.

The lower SOC stock determined for the studied soils in comparison with Haplic Cambisols in the Urals (Kammer et al., 2009) can be explained by greater biological activity in calcareous soils or more favorable climate conditions devoid of drought periods. The SOC stock determined for our study area was significantly smaller than that found in a similar environment in the Stołowe Mts., which are part of the Sudeten Mts. in southwestern Poland (Gałka et al., 2014). This can be explained by the fact that the soils in the studied area were much more shallow.

\subsection{Land use effects on OM fractions in soil}

In the studied soils, OM was mainly associated with the mineral part of the soil (Table 4), which is consistent with research results obtained for other soils in temperate climate zones, where more than $60 \%$ of the total SOC fraction is associated with the mineral part of soil (Jastrow, 1996; Don et al., 2009). OM in the soils studied can be divided into two main groups: (1) MOM FF fractions (MOM FF1, MOM FF2, MOM FF3) with a low $\mathrm{C} / \mathrm{N}$ ratio suggesting a relatively high contribution of humified as well as microorganismsderived OM, which is believed to serve as a factor that glues soil particles together inside microaggregates (Oades, 1984; Six et al., 2001), and (2) POM fractions (POM LF1, POM LF2) with a high $\mathrm{C} / \mathrm{N}$ ratio, which suggests relatively weakly decomposed plant-derived material (Table 5).

The highest mass of FF2 fractions in relation to the mass of the FF1 fraction in all the studied soils (Table 3) refers (Leifeld and Kögel-Knabner, 2005) to the relatively high structural stability linked with the development of water-stable aggregates in the studied soils, in comparison with sandy soils investigated by Leifeld and Kögel-Knabner (2005). This can be an effect of the calcium and magnesium carbonate content as well as the relatively high content of mineral colloids, which promote structural stability in soils (Oades, 1988; Muneer and Oades, 1989; Denef et al., 2004; Lützow et al., 2006; Grünberg et al., 2013). Similarly, in the studied soils, OM associated with the mineral part of the soil occurred mainly in macroaggregates (MOM FF2) and microaggregates (MOM FF3) (Tables 3, 4). In all the studied soils, the amount of SOC outside of water-stable aggregates (MOM FF1) was very small. The highest concentration of SOC in macroaggregates in the studied soils was consistent with results obtained by Jastrow (1996) and Debasish-Saha et al. (2014). The researchers independently concluded that this is the result of the transitional nature of macroaggregates, in comparison with microaggregates, which contain a relatively passive pool of OM because of strong bonds with clay minerals.
In soil under grassland, the largest amount of SOC bound within MOM FF3 (microaggregates OM) was found in contrast to soils found under coniferous communities (dwarf pine shrub and larch forest) (Table 4). This corresponds with the highest mass of FF3 and the lowest mass of FF1 and refers (Leifeld and Kögel-Knabner, 2005) to high structural stability linked with the development of stable microaggregates in soils under grassland. Conversely, the mass of the FF1 fraction was the largest in soils found under dwarf pine, while the largest part of SOM was stored in the MOM FF2 fraction. This shows that the soil structure was less stable (quantity of FF1 fraction) and most of the SOM occurred in more transitional aggregates (quantity of FF2 fraction) (Leifeld and Kögel-Knabner, 2005; Debasish-Saha et al., 2014).

The $\mathrm{C} / \mathrm{N}$ ratio in MOM did not change with depth along the soil profile (Table 4). The lowest $\mathrm{C} / \mathrm{N}$ ratio was observed in the MOM FF1 fraction, which was most likely due to less protection of OM from microbial attack outside water-stable aggregates (Lützow et al., 2006).

A much higher content of the POM LF1 and POM LF2 fractions in the soil under dwarf pine shrub versus that in soil under grassland and under larch forest was observed, both outside aggregates (POM LF1), as well as occluded in macroaggregates (POM LF2) (Table 4). The highest amount of the POM LF1 fraction seemed to confirm suppressing decomposition rates in soils under coniferous vegetation in contrast with grassland soils. This trend can be affected by the suppressing effect of coniferous plant material (lowered $\mathrm{pH}$ ) on soil microbial activity (Drewnik, 2006) as well as lower soil temperature that limits soil biological activity in forest ecosystems (Kim, 2000) or by the delivery of more recalcitrant plant material such as tree roots to the forest soil (Debasish-Saha et al., 2014). Budge et al. (2011) found - in Alpine soils - that the residence time of POM derived from dwarf shrubs was longer than the residence time of POM derived from grassland, although researchers have not settled upon whether this is the result of the suppressing effect of the plant community on microbial activity or if it is the result of higher recalcitrance of the material delivered to the soil.

The obtained results appear to confirm a very important role of the POM fraction as a precursor of macroaggregates (Lützow et al., 2006; Debasish-Saha et al., 2014; van Leeuven et al., 2015). OM was supplied to the soil functions as a nucleon-gluing soil colloid due to soil microbial activity. Results obtained by Debasish-Saha et al. (2014) show that the higher amount of the POM fraction in forest soils - in comparison with soils developed via other types of land use - directly leads to a higher abundance of macroaggregates in these soils. Van Leeuven et al. (2015) as well as Tejda and Benítez (2014) observed that OM delivery to soils found under meadows as well as to eroded agricultural soils causes a higher biomass of soil bacteria and fungi. In the special case of Icelandic meadows studied by van Leeuven et al. (2015), it leads to a higher mass of macroaggregates in these soils. 
OM occurring outside aggregates (POM LF1) was less decomposed than OM occluded in macroaggregates (POM LF2) in all the studied soils, as evidenced by the highest $\mathrm{C} / \mathrm{N}$ ratio (Table 5). This proves that relatively young organic material (poorly humified) is gradually incorporated into soil aggregates (cf. Oades, 1984; Six et al., 2001; Lützow et al., 2006; Budge et al., 2011). The $\mathrm{C} / \mathrm{N}$ ratio was observed to increase in the POM LF1 fraction with depth in all the studied soils (Table 5). This suggests that the primary precursors of POM formation are plant roots because the decomposition rate of $\mathrm{OM}$ increases with depth within $\mathrm{O}$ horizons developed as a result of litter accumulation on the mineral surface of the soil (i.e. C / $\mathrm{N}$ ratio decreases) (Ussiri and Johnson, 2003; Budge et al., 2011).

In contrast, the $\mathrm{C} / \mathrm{N}$ ratio in the POM LF2 fraction decreased with depth (Table 5), which indicates a higher decomposition rate for $\mathrm{OM}$ occluded in aggregates with depth. This can be the result of incorporation of weaklydecomposed, relatively fresh OM into the structures of aggregates, which occurred most rapidly in the top of the mineral part of soil (A1 horizon) in comparison with deeper horizons. In addition, this suggests the action of mechanisms that incorporate POM into soil aggregates found near the soil surface. This can include significant activity of soil fauna, which is abundant in calcareous soils (Zanella et al., 2011) in the top soil horizons and increased activity of microorganisms that live near the soil surface (Beier and Rasmussen, 1994).

\subsection{Management issues}

Research in the Jaworzynka Valley showed which method of renaturation is the most favorable in shallow eroded calcareous soils developed on steep slopes found in a temperate humid climate. This yields the following question: which solution is more advantageous? (1) Allow grassland to remain grassland; (2) carry our afforestation using sparse larch forest with a naturally developed dense cover of tall grass Calamagrostis sp. on the forest floor; and (3) plant dwarf pine shrub. All three methods effectively protect the soil against erosion, which was confirmed by the horizonation of all the studied soils - seen to be experiencing gradual soil stabilization (Targulian and Krasilnikov, 2007; Guzman et al., 2014).

The expected effect of soil reclamation and renaturation is SOC $(\mathrm{OM})$ sequestration, especially in resistant (mineralassociated, aggregated) forms, which leads to increased soil fertility, soil stability, and improved soil structure (resistance against erosion), and helps restrict $\mathrm{CO}_{2}$ emission into the atmosphere (Oades, 1984; Debasish-Saha et al., 2014; Fernández-Romero et al., 2014; Guzman et al., 2014). In this context, afforestation with sparse larch forest is the most effective solution, because soils under larch forest sequester the largest amount of SOC (Fig. 5), and a significant part of OM occurs in aggregates resistant to mechanical degradation and decomposition, especially in contrast with dwarf pine (cf. Oades, 1984; Leifeld and Kögel-Knabner, 2005; Debasish-
Saha et al., 2014). In soils found under meadow, most SOC is sequestered in mineral-associated form. This is advantageous in terms of SOC sequestration itself, but can be less favorable in terms of soil erosion, as smaller aggregates can be relatively easily moved by the wind and water as well as from the point of view of water and air retention and microorganism habitats in the soil (Oades, 1984; Barthès and Roose, 2002). In this context, the planting of dwarf pine and larch forest would be more beneficial.

Taking all relevant information into account, it appears that the planting of larch forest would be the optimal solution in the context of SOC sequestration, improvement of soil properties, and protection against erosion. Experimental data suggest that mixed-type vegetation such as grass on the forest floor protects the soil against erosion more effectively than forest vegetation with a bare forest floor and meadow does by itself (Mekonnen et al., 2014).

\section{Conclusions}

1. Fifty years since the conversion of pastureland to largely unused grassland, the emergence of dwarf pine shrub and larch forest in eroded calcareous soil, the development of genetic soil horizons as well as SOC sequestration in soil, occur despite the substantial steepness of the slope.

2. SOC stock was the highest in soils under larch forest, while in soil under dwarf pine shrub and under grassland, SOC stock was similar and smaller. Quantitatively, the most important issue here is SOC sequestration in the mineral part of the soil $(100 \%$ in grassland soil and $94 \%$ in larch forest); yet, in soils under dwarf pine shrub, a larger portion of SOC is retained in $\mathrm{O}$ horizons $(33 \%)$.

3. Although it has been only 50 years since the aforesaid conversion, differences in the amount of SOC sequestrated in each studied fraction do exist, depending on land use in the Jaworzynka Valley. SOM is retained in the most stable form in soil under grassland and in a little less stable form in soil under larch forest. The least stable forms of SOM are present in soil under dwarf pine shrub. In this regard, soil formed under larch forest with dense tall grass is much more similar to grassland soil than soil formed under dwarf pine shrub.

4. Under the assumption that the most favorable state is the state in which the SOM pool is higher and it is sequestered in resistant forms, the conclusion is that sparse larch with dense tall grass cover on the floor is the best choice in the process of renaturation of eroded carbonate soils in humic conditions. 
Acknowledgements. This work was supported by project no. $\mathrm{N}$ N305 381539 from the State Committee for Scientific Research (Warsaw, Poland). The authors would like to thank Tomasz Mączka of Tatra National Park in Poland and Michał Paszkowski for their assistance. Language editing was done by Greg Zebik.

Edited by: P. Pereira

\section{References}

Alfredsson, H., Condron, L. M., and Clarholm, M., and Davis, M. R.: Changes in soil acidity and organic matter following the establishment of conifers on former grassland in New Zeland, Forest Ecol. Manag., 112, 245-252, 1998.

Baldock, J. A. and Skjemstad, J. O.: Role of the soil matrix and minerals in protecting natural organic material against biological attack, Org. Geochem., 31, 697-710, 2000.

Barbera, V., Poma, I., Gristina, L., Nowara, A., and Egli M.: Longterm cropping systems and tillage management effects on soil organic carbon stock and steady state level of $\mathrm{C}$ sequestration rates in a semiarid environment, Land Degrad. Dev., 23, 82-91, 2012.

Barua, S. K. and Haque, N. S.: Soil characteristics and carbon sequestration potentials of vegetation in the degraded hills of Chittagong, Bangladesh, Land Degrad. Dev., 24, 63-71, 2013.

Barthès, B. and Roose, E.: Aggregate stability as an indicator of soil susceptibility to runoff and erosion; validation at several levels, Catena, 47, 133-149, 2002.

Batjes, N. H.: Projected changes in soil organic carbon stocks upon adoption of recommended soil and water practices in the Upper Tana River Catchment, Kenia, Land Degrad. Dev., 25, 278-287, 2014

Beier, C. and Rasmussen, L.: Organic Matter Decomposition in an Acidic Forest Soil in Denmark as Measured by the Cotton Strip Assay, Scand. J. Forest Res., 9, 106-114, 1994.

Błażejczyk, K., Baranowski, J., Błażejczyk, A., and Szmyd, J.: Climate and bioclimate of Hala Gasienicowa, Prace Geograficzne IGiPZ PAN, 239, 67-95, 2013.

Bochter, R. and Zech, W.: Organic compounds in Cryofolists developed on limestone under subalpine coniferous forest, Bavaria, Geoderma 36, 145-157, 1985.

Brevik, E. C., Cerdà, A., Mataix-Solera, J., Pereg, L., Quinton, J. N., Six, J., and Van Oost, K.: The interdisciplinary nature of SOIL, SOIL, 1, 117-129, doi:10.5194/soil-1-117-2015, 2015.

Bruun, T. D., Elberling, B., De Neergaard, A., and Magid, J.: Organic carbon dynamics in different soil types after conversion of forest to agriculture, Land Degrad. Dev., 26, 272-283, 2015.

Budge, K., Leifeld, J., Hiltbrunner, E., and Fuhrer, J.: Alpine grassland soils contain large proportion of labile carbon but indicate long turnover times, Biogeosciences, 8, 1911-1923, doi:10.5194/bg-8-1911-2011, 2011.

Corral-Fernández, R., Parras-Alcántara, L., and Lozano-García, B.: Stratification ratio of soil organic $\mathrm{C}, \mathrm{N}$ and $\mathrm{C}: \mathrm{N}$ in Mediterranean evergreen oak woodland with conventional and organic tillage, Agr. Ecosyst. Environ., 164, 252-259, 2013.

Corre, M. D., Schnabel, R. R., and Shaffer, J. A.: Evaluation of soil organic carbon under forests, cool-season and warm-season grasses in the northern US, Soil Biol. Biochem., 31, 1531-1539, 1999.

Debasish-Saha, S. S., Kukal, S. S., and Bawa, S. S.: Soil organic carbon stock and fractions in relation to land use and soil depth in the degraded Shiwaliks hills of Lower Himalayas, Land Degrad. Dev., 25, 407-416, 2014.

Denef, K., Six, J., Merkckx, R., and Paustian, K.: Carbon Sequestration in Microaggregates of No-Tillage Soils with Different Clay Minerology, Soil Sci. Am. J., 68, 1935-1944, 2004.

Didier, L.: Invasion patterns of European larch and Swiss stone pine in subalpine pastures in the French Alps, Forest Ecol. Manag., 145, 67-77, 2001.

Don, A., Schumacher, J., Scherer-Lorenzen, M., Scholten, T., and Schulze, E.-D.: Spatial and vertical variation of soil carbon at two grassland sites - Implications for measuring soil carbon stocks, Geoderma, 141, 272-282, 2007.

Don, A., Scholten, T., and Schulze, E.-D.: Conversion of cropland into grassland: Implications for soil organic-carbon stocks in two soils with different texture, J. Plant Nutr. Soil Sci., 172, 53-62, 2009.

Drewnik, M.: The effect of environmental conditions on the decomposition rate of cellulose in mountain soils, Geoderma, 132, 116130, 2006.

Fernández-Romero, M. L., Lozano-García, B., and ParrasAlcántara, L.: Topography and land use change effects on the soil organic carbon stock of forest soils in Mediterranean natural areas, Agr. Ecosyst. Environ., 195, 1-9, 2014.

Fialho, R. C. and Zinn, L.: Changes in soil organic carbon under Eucalyptus plantations in Brazil: a comparative analysis, Land Degrad. Dev., 25, 428-437, 2014.

Gałka, B., Łabaz, B., Bogacz, A., Bojko, O., and Kabała, C.: Conversion of Norway spruce forests will reduce organic carbon pools in the mountain soils of SW Poland, Geoderma, 213, 287295, 2014.

Gee, G. W. and Bauder, J. W.: Particle-size analysis, in: Methods of Soil Analysis, Part 1, Physical and Mineralogical Methods, edited by: Klute, A., ASA-SSSA, Madison, Wisconsin, 427-445, 1986.

Grüneberg, E., Schöning, I., Hessenmöller, D., Schulze, E.-D., and Weisser, W. W.: Organic layer and clay content control soil organic carbon stock in density fractions of differently managed German beech forests, Forest Ecol. Manag., 303, 1-10, 2013.

Guo, L. B. and Gifford, R. M.: Soil carbon stocks and land use change: a meta-analysis, Glob. Change Biol., 8, 345-360, 2002.

Guzman, J. G., Lal, R., Byrd, S., Apfelbaum, S. I., and Thompson, L.: Carbon life cycle assessment for prairie as a crop in reclaimed mine land, Land Degrad. Dev., doi:10.1002/ldr.2291, 2014.

Halliday, J. C., Tate, K. R., McMurtrie, R. E., and Scott, N. A.: Mechanisms for changes in soil carbon storage with pasture to Pinus radiata land-use change, Glob. Change Biol., 4, 1294 1308, 2003.

IUSS Working Group WRB: World reference base for soil resources 2006, World Soil Resources Reports No. 103, FAO, Rome, 2006 (update 2007).

Jaiarree, S., Chidthaisong, A., Tangtham, N., Polprasert, C., Sarobol, E., and Tyler, C.: Carbon budget and sequestration potential in a sandy soil treated with compost, Land Degrad. Dev., 25, 120-129, 2014. 
Jastrow, J. D.: Soil aggregate formation and the accrual of particulate and mineral-associate organic matter, Soil Biol. Biochem., 28, 665-676, 1996.

Jenny, H.: Hochgebirgsböden, in: Handbuch der Bodenlehre, edited by: Blanck, E., Verlag von Julius Springer, 96-118, 1930.

Jindaluang, W., Kheoruenromne, I., Suddhiprakarn, A., Singh, B. P., and Singh, B.: Influence of soil texture and mineralogy on organic matter content and composition in physically separated fractions soils in Thailand, Geoderma, 195-196, 207-219, 2013.

Johnson, D. W., Todd Jr., D. E., and Tolbert, V. R.: Changes in Ecosystem Carbon and Nitrogen in Loblolly Pine Plantation over the First 18 Years, Soil Soc. Am. J., 67, 1594-1601, 2003.

Jonczak, J.: Dynamics, structure and properties of plant litterfall in a 120-year old beech stand in Middle Pomerania between 20072010, Soil Science Annual, 64, 8-13, 2013.

Kammer, A., Hagedorn, F., Shevchenko, I., Leifeld, J., Guggenberger, G., Goryacheva, T., Rigling, A., and Moiseev, P.: Treeline shifts in the Ural mountains affected organic matter dynamics, Glob. Change Biol., 15, 1570-1583, 2009.

Keesstra, S. D., Geissen, V., Mosse, K., Piiranen, S., Scudiero, E., Leistra, M., and Schaik, L. v.: Soil as a filter for groundwater quality, Current Opinion in Environmental Sustainability, 4, 507516, 2012.

Kim, C.: Canopy Cover Effects on Cellulose Decomposition in Oak and Pine Stands, J. For. Res., 5, 145-149, 2000.

Kubiena, W.: Alpine soils on limestone: spatial variations, Micromorphological Features of Soil Geography, Ruthers Univ. Press, New Brunswick, New Jersey, 1953.

Laganière, J., Angers, D. A., and Parè, D.: Carbon accumulation in agricultural soils after afforestation: a meta-analysis, Glob. Change Biol., 16, 439-453, 2010.

Laganière, J., Angers, D. A., Paré, D., Bargeron, Y., and Chen, H. Y. H.: Black Spruce Accumulate More Uncomlexed Organic Matter than Aspen Soils, Soil Sci. Soc. Am. J., 75, 1125-1132, 2011.

Leifeld, J. and Kögel-Knabner, I.: Soil organic matter as early indicators for carbon stock changes under different land-use?, Geoderma, 124, 143-155, 2005.

Leifeld, J., Zimmerman, M., Fuhrer, J., and Conen, F.: Storage and turnover of carbon in grassland soils along an elevation gradiend in the Swiss Alps, Glob. Change Biol., 15, 668-679, 2009.

Lozano-García, B. and Parras-Alcántara, L.: Land use and management effects on carbon and nitrogen in Mediterranean Cambisols, Agr. Ecosyst. Environ., 179, 208-214, 2013.

Lützow, M. v., Leifeld, J., Kainz, M., Kögel-Knabner, I., and Munch, J. C.: Indicators for soil organic matter quality in soils under different management, Geoderma, 105, 243-258, 2002.

Lützow, M. v., Kögel-Knabner, I., Ekschmitt, K., Matzner, E., Guggenberger, G., Marschner, B., and Flessa, H.: Stabilization of organic matter in temperate soils: mechanisms and their relevance under different soil conditions - a review, Eur. J. Soil Sci., 57, 426-445, 2006.

Martinsen, V., Mulder, J., Autrheim, G., and Mysterud, A.: Carbon storage in low-alpine grassland soils: effect of different grazing intensities of sheep, Eur. J. Soil Sci., 62, 822-833, 2011.

Mekonnen, M., Keesstra, S. D., Stroosnijder, L., Baartman, J. E. M., and Maroulis, J.: soil conservation through sediment trapping: a review, Land Degrad. Dev., 26, 544-556, doi:10.1002/ldr.2308, 2014.
Miechówka, A.: Characteristics of Tatra non-forest soils derived from carbonate rocks, Rozprawy Akademii Rolniczej w Krakowie, 2000.

Muneer, M. and Oades, J. M.: The role of Ca-organic interactions in soil aggregate stability 2 Field studies with ${ }^{14} \mathrm{C}$-labelled straw, $\mathrm{CaCO}_{3}, \mathrm{CaSO}_{4} \cdot 2 \mathrm{H}_{2} \mathrm{O}$, Aust. J. Soil Res., 27, 401-409, 1989.

Murty, D., Kirchbaum, M. U. F., McMurtrie, R. E., and McGilvray, H.: Does conversion of forest to agricultural land change soil carbon and nitrogen? A review of literature, Glob. Change Biol., 8, 105-123, 2002.

Oades, J. M.: Soil organic matter and structural stability: mechanisms and implications for management, Plant Soil, 76, 319-337, 1984.

Oades, J. M.: The retention of organic matter in soils, Biogeochemistry, 5, 35-70, 1988.

Oyama, M. and Takehara, H. (Eds.): Revised standard soil color charts, Research Council for Agriculture, Forestry, and Fisheries, Ministry of Agriculture, and Agriculture, Japan, 2002.

Parras-Alcántara, L., Díaz-Jaimes, L., Lozano-García, B., Fernández Rebollo, P., Moreno Elcure, F., and Carbonero Muñoz, M. D.: Organic farming has little effect on carbon stock in a Mediterranean dehesa (southern Spain), Catena, 113, 9-17, 2014.

Paul, K. I., Polglase, J. G., Nyakuengama, J. G., and Khanna, P. K.: Change in soil carbon following afforestation, Forest Ecol. Manag., 168, 241-257, 2002.

Paul, E. A., Morris, S. J., Six, J., Paustian, K., and Gregorich, E. G.: Interpretation of Soil Carbon and Nitrogen Dynamics in Agricultural and Afforested Soils, Soil Sci. Soc. Am. J., 67, 1620-1628, 2003.

Pikul Jr., J. L., Osborne, S., Ellsbury, M., and Riedell, W.: Particulate Organic Matter and Water-Stable Aggregation in Soils under Contrasting Management, Soil Sci. Soc. Am. J., 71, 766-776, 2007.

Plante, A. F., Contant, R. T., Steward, C. E., Paustian, K., and Six, J.: Impact of Soil Texture on the Distribution of Soil Organic Matter in Physical and Chemical Fractions, Soil Sci. Soc. Am. J., 70, 287-296, 2006.

Poeplau, C. and Don, A.: Sensitivity of soil organic carbon stocks and fractions to different land-use changes across Europe, Geoderma, 192, 189-201, 2013.

Post, W. M. and Kwon, K. C.: Soil carbon sequestration and landuse change: processes and potential, Glob. Change Biol., 6, 317327, 2000.

Prichard, S. J., Peterson, D. L., and Hammer, R. D.: Carbon distribution in subalpine forests and meadows of the Olympic Mountains, Washington, Soil Sci. Soc. Am. J., 64, 1834-1845, 2000.

Rigueiro-Rodríguez, A., Mosquera-Losada, M. R., and FernándezNúñez, E.: Afforestation of agricultural land with Pinus radiata D. Don and Betula alba L. in NW Spain: effects of soil pH, understory production and floristic diversity eleven years after establishment, Land Degrad. Dev., 23, 227-241, 2012.

Schoenerberger, P. L., Wysocki, D. A., Benham, E. C., and Broderson, W. D. (Eds.): Field book for describing and sampling soils, Version 2.0, Natural Resources Conservation Service, National Soil Survey Center, Lincoln, NE, 2002.

Seeber, J. and Seeber, G. U. H.: Effects of land-use changes on humus forms on alpine pastureland (Central Alps, Tyrol), Geoderma, 124, 215-222, 2005. 
Six, J., Guggenberger, G., Paustian, K., Haumaier, L., Elliott, E. T., and Zech, W.: Sources and composition of soil organic matter fractions between and within soil aggregates, Eur. J. Soil Sci., 52, 607-618, 2001.

Six, J., Conant, R. T., Paul, E. A., and Paustian, K.: Stabilization mechanisms of soil organic matter: Implications for C-saturation of soils, Plant Soil, 241, 155-176, 2002.

Skiba, S.: Tendencies towards zonality in the rendzinas of the Tatra Mts. (with the soils of the slopes of Mt. Kominiarski Wierch as an example), Rocz. Gleb., 34, 101-112, 1983.

Sokołowski, S. and Jaczynowska, W.: Geological map of Polish Tatra Mts.: A4 Kopieniec, Wydawnictwa Geologiczne, Warszawa, 1979.

Srinivasa, R. Ch., Venkateswarlu, B., Lal, R., Singh, A. K., Kundu, S., Vittal, K. P. R., Patel, J. J., and Patel, M. M.: Long-term manuring and fertilizer effects on the depletion of soil organic carbon stocks under pearl millet-cluster bean-castor rotation in Western India, Land Degrad. Dev., 25, 173-183, 2014.

Steward, C. E., Plante, A. F., Paustian, K., Contant, R. T., and Six, J.: Soil Carbon Saturation: Linking Concept and Measurable Carbon Pools, Soil Sci. Soc. Am. J., 72, 379-392, 2008.

Targulian, V. O. and Krasilnikov, P. V.: Soil system and pedogenic processes; Self-organization, time scales, and environmental significance, Catena, 71, 373-381, 2007.

Tate, K. R., Scott, N. A., Ross, D. J., Parshotam, A., and Claydon, J. J.: Plant effects on soil carbon storage and turnover in a montane beech (Nothofagus) forest and adjacent tussock grassland in New Zealand, Aust. J. Soil Res., 38, 685-698, 2000.

Tejda, M. and Benítez, C.: Effects of crushed maize straw residues on soil biological properties and soil restoration, Land Degrad. Dev., 25, 501-509, 2014.
Thomas, G. W.: Soil pH and soil acidity, in: Methods of Soil Analysis, Part 3, Chemical Methods, edited by: Sparks, D. L., Page, A L., Helmke, P. A., Loeppert, R. H., Soltanpour P. N., Tabatabai, M. A., Johnston, C. T., and Sumner, M. E., SSSA and ASA, Madison, Wisconsin, 475-490, 1996.

Ussiri, D. A. N. and Johnson, C. E.: Characterization of organic matter in a northern hardwood forest soil by ${ }^{13} \mathrm{C}$ NMR spectroscopy and chemical methods, Geoderma, 111, 123-149, 2003.

van Leeuwen, J. P., Lehtinen, T., Lair, G. J., Bloem, J., Hemerik, L., Ragnarsdóttir, K. V., Gísladóttir, G., Newton, J. S., and de Ruiter, P. C.: An ecosystem approach to assess soil quality in organically and conventionally managed farms in Iceland and Austria, SOIL, 1, 83-101, doi:10.5194/soil-1-83-2015, 2015.

Wang, W.-J., Qiu, L., Zu, Y.-G., Su, D.-X., An, J., Wang, H.-Y., Zheng, G.-Y., Sun, W., and Chen, X.-Q.: Changes in soil organic carbon, nitrogen, $\mathrm{pH}$ and bulk density with the development of larch (Larix gmelinni) plantations in China, Glob. Change Biol., 17, 2657-2676, 2011

Zanella, A., Jabiol, B., Ponge, J. F., Sartori, G., De Waal, R., Delft, B. v., Graefe, U., Cools, N., Katzensteiner, K., Hager, H., and Englisch, M.: A European morpho-functional classification of humus forms, Geoderma, 164, 138-145, 2011.

Zhang, J. J., Fu, M. C., Zeng, H., Geng, Y. H., and Hassani, F. P.: Variations in Ecosystem Service Values and local economy in response to land use: a case study of Wu' an, China, Land Degrad. Dev., 24, 236-249, 2013.

Zhao, G., Mu, X., Wen, Z., Wang, F., and Gao, P.: Soil erosion, conservation, and eco-environment changes in the Loess Plateau of China, Land Degrad. Dev., 24, 499-510, 2013. 